\title{
Application of Making MOLs in Rice Planting with Organic Systems in Subak Pacung, Selat Village, Abiansemal Sub-district, Badung
}

\author{
Anak Agung Sagung Putri Risa Andriani ${ }^{1}$, Ni Made Ayu Gemuh Rasa Astiti ${ }^{2}$ and Ni Ketut \\ Mardewi ${ }^{3}$
}

Warmadewa University

\begin{abstract}
Subak Pacung located in Selat Village, Abian Semal Sub-district, Badung Regency, is one of the partnering communites in the implementation of PKM (Community Partnership Program). This group always experiences problems due to the use of chemical fertilizers and pesticides which increasingly damage the soil structure and pollutes the environment. Furthermore, the use of chemical fertilizers triggers poor soil quality, environmental pollution and increases greenhouse gas emissions which leads to a rise in global warming. Therefore, it is necessary to develop alternative strategies to manufacture cheap and envrionmentally friendly organic fertilizers with same benefits as the chemical. Organic fertilizers made from local micro organisms have similar benefits with decomposers or ingredients for composting, liquid organic fertilizer, and vegetable pesticides. Data were obtained through face-to-face interviews, counseling and direct practice. The activities were carried out as follows: Firstly, a general counseling was held on the dangers of using chemical fertilizers and pesticides, as well as analysis on the benefits and methods of making Local Micro Organisms (MOL). Secondly, direct training was carried out in making MOL and several evaluations. Thirdly, an ends to the PKM activity, motivates farmers to apply the use of MOL as organic fertilizers and pesticides in rice planting. The result shows that the output target to be achieved is the training participants ability to understand the methods of making MOL, in order to reduce the use of chemical fertilizers and pesticides.
\end{abstract}

Keywords : Abian Semal Sub-district, Selat Village, Rice, MOL

\section{Pendahuluan}

Subak Pacung merupakan salah satu subak yang ada di Desa Selat, Kecamatan Abiansemal Kabupaten Badung yang memiliki potensi dalam bidang pertanian. Secara geografis, wilayah desa Selat Kecamatan Abiansemal kabupaten Badung terletak di 8o LS, dan 115o BT dengan ketinggian \pm 400 mdpl dan luasnya sekitar 221 hektar. Secara administrasi, desa selat terdiri dari 4 banjar dinas meliputi Banjar Dinas Selat Anyar, Banjar Dinas Selat, Banjar Dinas Tegal dan Banjar Dinas Mekar sari. Wilayah Desa Selat sebagian besar diperuntukan sebagai lahan 
persawahan, ladang, pemukiman, dan bangunan umum. Batas wilayah desa Selat meliputi di sebelah utara berbatasan dengan desa Samuan kecamatan petang, di sebelah selatan berbatasan dengan desa Blahkiuh, di sebelah barat berbatasan dengan desa Sangeh, dan di sebelah timur berbatasan dengan desa Taman.

Jumlah penduduk desa Selat hingga tahun 2017 sebanyak 665 kepala keluarga atau sekitar 2376 jiwa yang terdiri dari 1151 orang laki-laki dan 1225 orang perempuan. Secara umum penduduk desa Selat sebagian besar bekerja dalam sektor pertanian, perkebunan, dan sisanya berfrofesi sebagai pegawai swasta/, PNS, maupun wiraswasta. Desa Selat ini memiliki potensi pengembangan pertanian khususnya budidaya padi mengingat di daerah tersebut terdapat hamparan sawah yang luas dan secara geografis juga mendukung pertumbuhan budidaya padi.

Mitra mengeluhkan penggunaan pupuk kimia dan pestisida kimia yang semakin merusak struktur tanah dan dapat mencemari lingkungan. Pupuk kimia dapat memicu rendahnya kualitas tanah, pencemaran lingkungan serta semakin meningkatnya emisi gas rumah kaca memberikan resiko pemanasan global yang semakin tinggi. Oleh karena itu, perlu diberikan alternatif pembuatan pupuk organik yang murah dan ramah lingkungan serta memiliki manfaat sama dengan pupuk kimia. Pupuk organik yang dibuat dari Mikro Organisme Lokal memiliki manfaat pupuk organik cair, decomposer atau biang pembuatan kompos, dan pestisida nabati. Prioritas yang ditangani adalah :

1. Mendapatkan Ipteks dalam pertanian khususnya petani Padi

2. Mendapatkan pengetahuan bahaya penggunaan pupuk dan pestisida kimia

3. Mendapatkan pengetahuan mengenai pembuatan MOL sebagai pupuk organik dan pestisida alami

4. Mendapatkan beberapa contoh MOL dan alat-alat penunjang pembuatan MOL.

\section{Metodelogi Pelaksanaan}

\subsection{Metode}

Metode pelaksanaan kegiatan PKM Aplikasi penggunaan MOL dalam penanaman padi yang direncanakan yaitu menggunakan:

1. Metode Wawancara dan diskusi untuk dapat mengetahui permasalahan yang dialami mitra.

2. Metode tatap muka dan memberikan penyuluhan secara langsung, agar mitra mendapatkan pengetahuan mengenai cara pembuatan MOL dan dapat menerapkan langsung dalam penanaman padi.

3. Praktek langsung, yang dipandu oleh instruktur yang berkompeten dibidangnya, sehingga mitra dapat menerapkan langsung metode yang diberikan..

\subsection{Rencana dan Prosedur Kegiatan}

Rencana dan Prosedur Kegiatan IbM yang akan dilaksanakan yaitu :

1. Pendekatan kepada kelompok, pemilihan tempat sekaligus memilih peserta, yang selanjutnya akan disebut sebagai peserta pelatihan. 
2. Wawancara dan Tanya jawab mengenai permasalahan yang dihadapi mitra, sekaligus merencanakan kegiatan yang menunjukkan langkah-langkah solusi atas persoalan yang dihadapi.

3. Mitra terlebih dahulu akan diberikan materi yang telah disiapkan oleh tim dalam bentuk modul mengenai cara pembuatan beberapa MOL dan penerapannya dalam penanaman Padi

4. Penerapan langsung ke petani

5. Jika masa pelaksanaan kegiatan akan berakhir, akan diserahkan beberapa contoh beberapa MOL dan alat untuk menunjang usaha.

\subsection{Partisipasi Mitra}

1. Mitra/peserta pelatihan diharapkan mentaati semua kesepakatan yang telah dibuat.

2. Mitra diharapkan disiplin dan sungguh-sungguh melaksanakan semua rangkaian kegiatan sampai semua rencana kegiatan berakhir.

3. Setelah kegiatan PKM berakhir mitra diharapkan mampu melanjutkan kegiatan dengan baik dan usaha yang dirintis dapat berkembang

\subsection{Luaran}

a. Mampu mengurangi penggunaan pupuk kimia dan pestisida kimia dalam penanaman padi

b. Mampu mengurangi pencemaran lingkungan dan emisi gas rumah kaca.

\section{Hasil Dan Pembahasan}

Kegiatan Program Kemitraan Masyarakat dengan judul aplikasi pembuatan beberapa MOL pada penanaman padi dengan sistem organik telah berjalan dengan lancar di Subak Pacung Desa Selat, Kecamatan Abiansemal Kabupaten Badung. Kegiatan pertama berupa penyuluhan-penyuluhan atau kajian teori untuk memberikan pemahaman mengenai materi penunjang dan pentingnya manfaat dari MOL sebagai pupuk organik dan pestisida alami yang dihadiri oleh 20 orang dari kelompok Tani Wanita disertai Kepala Subak. Tim penyuluh juga memberikan sumbangan alat dan bahan untuk pembuatan MOL. Kegiatan Kedua yaitu berupa pengenalan MOL secara langsung, pengenalan bahan-bahan yang digunakan dan pembuatan MOL sehingga kelompok Tani sudah memahami dan mampu membuat langsung MOL. Kegiatan Ketiga yaitu monitoring dan evaluasi dari penyuluh untuk memastikan mitra memahami materi yang diberikan dan sudah mampu membuat MOL. Dari hasil monitoring dan evaluasi, Kelompok Tani telah mampu membuat dan mengaplikasikan MOL di tanaman Padi.

Tabel 1. Kegiatan dan luaran yang dihasilkan Subak Pacung Desa Selat, Kecamatan Abiansemal Kabupaten Badung

\begin{tabular}{llll}
\hline No & Kegiatan & Luaran & Keterangan \\
\hline
\end{tabular}




\begin{tabular}{|c|c|c|c|}
\hline 1 & $\begin{array}{l}\text { Penyuluhan dan Pemberian } \\
\text { Materi tentang Pembuatan } \\
\text { MOL }\end{array}$ & $\begin{array}{l}\text { Materi penyuluhan berupa } \\
\text { leaflet }\end{array}$ & $\begin{array}{l}\text { Kelompok Tani sudah memaham } \\
\text { materi tentang Pembuatan MOL } \\
\text { sebagai pupuk organik }\end{array}$ \\
\hline 2 & $\begin{array}{l}\text { Penyiapan } \\
\text { Pembuatan MOL }\end{array}$ & $\begin{array}{l}\text { Alat dan } \\
\text { Pembuatan MOL }\end{array}$ & $\begin{array}{l}\text { Kelompok Tani sudah mampu } \\
\text { menyiapkan bahan yang ada } \\
\text { disekitar dibantu oleh Tim } \\
\text { Penyuluh }\end{array}$ \\
\hline 2 & $\begin{array}{ll}\text { Praktek } & \text { Langsung } \\
\text { Pembuatan MOL } & \end{array}$ & $\begin{array}{l}\text { Dihasilkan produk MOL } \\
\text { sebagai pupuk organik dan } \\
\text { pestisida nabati }\end{array}$ & $\begin{array}{l}\text { Kelompok Tani sudah mampu } \\
\text { membuat MOL sendiri }\end{array}$ \\
\hline 3 & $\begin{array}{l}\text { Pengaplikasian } \\
\text { Tanaman Padi }\end{array}$ & $\begin{array}{l}\text { Kelompok Tani } \\
\text { mengaplikasikan } \\
\text { langsung MOL } \\
\text { dibuat sendiri } \\
\text { Tanaman Padi }\end{array}$ & $\begin{array}{l}\text { Kelompok Tani sudah } \\
\text { mengaplikasikan MOL secara } \\
\text { benar sesuai dengan dosis dan } \\
\text { konsentrasi yang tepat }\end{array}$ \\
\hline 4 & Monitoring dan Evaluasi & $\begin{array}{l}\text { Kelompok tani sudah pasti } \\
\text { berhasil menerapkan } \\
\text { metode yang diberikan }\end{array}$ & $\begin{array}{l}\text { Kelompok Tani sudah } \\
\text { menerapkan saran dan sudah } \\
\text { melihat hasil dari pengaplikasian } \\
\text { MOL pada Tanaman Padi }\end{array}$ \\
\hline
\end{tabular}

\section{Kesimpulan Dan Saran}

Dari hasil kegiatan program kemitraan masyarakat dengan judul aplikasi pembuatan beberapa MOL pada penanaman padi dengan sistem organik telah berjalan dengan lancar di Subak Pacung Desa Selat, Kecamatan Abiansemal Kabupaten Badung dapat disimpulkan bahwa Kelompok Tani telah mampu membuat MOL sendiri dari limbah pertanian yang ada disekitarnya denga biaya yang murah serta sudah mampu mengaplikasikan pada Tanaman Padi dan telah melihat manfaat pemberian MOL secara langsung.

Disarankan kepada Kelompok Tani untuk memanfaatkan limbah pertanian di sekitarnya sebagai bahan pembuatan MOL secara kontinue dan berkelanjutan..

\section{References}

[1] Direktorat Jenderal Tanaman Pangan, Direktorat Perlindungan Tanaman Pangan.2008. Eksplorasi, Identifikasi dan Pembiakan Massal. Jakarta

[2] Direktorat Perlindungan Hortikultura, Direktorat Jenderal Hortikultura, Kementerian Pertanian Republik Indonesia.2015. Pedoman Identifikasi Agen Hayati/Musuh Alami.Jakarta.

[3] Murbando. 2013 : 19. Memproduksi kompos dan mikro organisme lokal (MOL). Jakarta Timur. Bibit Publisher

[4] Sutedjo, M. M. 2002. Pupuk Dan Cara Penggunaan. Jakarta : Rineka Cipta.

[5] Nisa, kalimatu. Dkk. (2016). Memproduksi kompos dan mikroorganisme lokal (MOL). Jakarta Timur. Bibit Publisher. 